\title{
Obstacles to implementing the UN Guiding Principles on Business and Human Rights in Southeast Asia
}

Edition 3, 2020

Dr Kate Macdonald

DOI: 10.37839/MAR2652-550X3.8

In June 2011, the United Nations Human Rights Council (UNHRC) unanimously passed the United Nations Guiding Principles on Business and Human Rights (UNGPs), amidst an atmosphere of cautious optimism. These principles provided a new set of global standards for preventing and addressing adverse human rights impacts associated with business activity, and have been described as the single most important innovation in the human rights and business field in the last 25 years'. Indonesia, Malaysia and Thailand-members of the UNHRC at the time the UNGPs were adopted-all voted in support of the framework, and several governments in the region subsequently indicated a potential willingness to develop National Action Plans to guide implementation. Nonetheless, almost ten years since the endorsement of the UNGPs, their implementation within Southeast Asia has remained slow and uneven.

\section{Business and human rights challenges in Southeast Asia}

Transnational business activity remains an important driver of economic growth and development in Southeast Asia. Over the last few decades, increased economic growth and integration in the Asia-Pacific region has been associated with the rapid expansion of business activity in large-scale infrastructure, energy and industrial 
projects, natural resource extraction, and land-intensive agribusiness sectors. While offering some parts of the population new economic opportunities and pathways out of poverty, such economic strategies have also been associated with significant human rights risks.

Business activity in many sectors-including agribusiness, logging, mineral extraction, energy, infrastructure and real estate-has been linked to land conflicts resulting from forced evictions or displacement, violations of rights to free, prior and informed consent for land transfers, and disputes over compensation for loss of land. Broader environmental impacts of business activity have frequently been associated with negative consequences for the health and livelihoods of local populations, whether through air and water pollution linked to industrial, extractive or infrastructure projects, or through the disruptive impacts of such projects on river or forest systems on which the livelihoods of many communities continue to depend. Violations of internationally recognised labour rights have also been widespread, including forced and child labour, migrant labour abuse and trafficking, inadequate wages, and poor health and safety conditions. Also attracting rising concern in recent years have been threats to the lives and safety of human rights defenders such as unionists and environmental activists, who have often experienced violence, arbitrary detention or criminal prosecution. These human rights threats have been further complicated by the ongoing consequences of the COVID-19 pandemic, which has generated new and intensified threats for vulnerable communities and workers across the region.

\section{The promise of the UNGPs}

In response to pervasive human rights risks of these kinds, the UNGPs declared that states have a duty to protect people against human rights abuses including by businesses; businesses have a responsibility to respect the human rights of others; and both have an obligation to ensure that victims of human rights abuses have access to effective remedies. Since formal endorsement of the UNGPs in 2011, the 
UN has moved to promote their implementation across the globe-spearheaded by the UN Working Group on Business and Human Rights.

The central architect of the UNGP framework was John Ruggie-a Harvard Professor who served as UN Special Representative for Business and Human Rights for the sixyear period from 2005-2011 during which the UNGPs were developed. Ruggie's intellectual origins as a prominent 'constructivist' international relations scholar visibly informed his conceptualisation of the causal processes through which UNGP diffusion and implementation were intended to unfold. Ruggie placed significant emphasis on the importance of collaborative processes of network-building, socialisation and learning as means of constructing a common knowledge base surrounding business and human rights-in turn influencing the beliefs and behaviours of business and government actors. Through building collaborative communities of practice focused on fostering new understandings of socially appropriate practices for managing human rights risks amongst powerful state and business actors, it was hoped that the UNGPs could ultimately become embedded in transformed identities and interests of business actors, supporting broad-based implementation of these new international norms.

In practical terms, promoting such processes of socialisation and learning was viewed as dependent on the creation, consolidation and expansion of collaborative learning networks. Ruggie saw these as providing crucial social infrastructures through which communities of practice committed to business and human rights norms could emerge and solidify, fostering common understandings of business and human rights challenges, and building shared knowledge about potential responses. Recognising that the UN human rights system lacks direct enforcement powers, Ruggie argued that such networked processes of norm promotion would need to unfold through a diffuse array of pre-existing networks, outside as well as within the inter-governmental structures through which international human rights norms have traditionally been disseminated. In this sense, the UNGPs were not intended to rely on their own implementation structures, but rather to catalyse cascading processes of dissemination and learning through dispersed institutional processes. 


\section{Adoption of elements of the UNGPs}

Globally, numerous examples have been documented in which elements of the UNGPs have been incorporated into norms or guidelines propagated by international standard-setting bodies, including ISO standards, OECD Guidelines for Multinational Enterprises, International Finance Corporation sustainability policies and the European Commission's Corporate Social Responsibility (CSR) Strategy. Such initiatives have been further supported by government and business human rights commitments in specific industry sectors, and via use of the UNGPs by civil society and worker organisations as advocacy and accountability tools. UNGP implementation has varied significantly across different countries and regions, making particular progress in Europe, where numerous governments have adopted National Action Plans on Business and Human Rights, and the European Commission has announced plans to introduce legislation mandating corporate human rights due diligence.

Although UNGP dissemination and implementation in Southeast Asia has lagged behind some other parts of the world, partial processes of dissemination are clearly evident. Within Southeast Asia, the UNGPs have been promoted through networks of both public and private actors at national, regional and transnational scales.

Central to dissemination of the UNGPs within Southeast Asia has been the mobilisation of national policy networks through which varying combinations of government, business and civil society actors have coordinated efforts to promote UNGP implementation. Of particular significance have been national conversations around the prospective development of National Action Plans (NAPs) on Business and Human Rights. These are government-led policy frameworks that articulate state priorities and planned actions to support implementation of the UNGPs, usually developed in consultation with a range of stakeholders inside and outside of government. Although there has been significant debate about the value of NAPs as means of promoting business and human rights, processes of debating or developing 
such plans have provided important focal points for promotion of the agenda within Southeast Asia. A number of ASEAN countries-including Indonesia, Malaysia and Myanmar-have made varying forms of progress in developing draft NAPs, though at the time of writing Thailand is the only ASEAN country to have completed negotiations surrounding development of such a Plan. In Indonesia, Malaysia, the Philippines and Thailand, National Human Rights Institutions have played significant roles within such networks, not only in promoting NAPs, but also in handling allegations of ongoing business-related human rights abuses within their own countries or elsewhere in the region.

At the national level, business networks, often led by prominent multinational companies, have also played a highly visible role in promoting the UNGPs. National Global Compact networks-established to promote the UN Global Compact's social and environmental sustainability principles-operate in the majority of ASEAN companies, providing an established institutional architecture through which the UNGPs can be disseminated. Business Chambers and Federations have sometimes also played a role in coordinating dialogue surrounding global CSR and human rights norms with members, including in countries in which Global Compact Networks have not been established. Prominent multinational companies are frequently involved in these networks-their leverage over wider business networks and supply chains providing a further channel through which the UNGPs can be disseminated. Support has also been provided by some local companies seeking to gain global recognition as world class companies through alignment with international standards, or those seeking to gain access to international investment or supply chain relationships which demand compliance with international standards. Some stock exchanges in the region have played a role in promoting awareness of the UNGPs, alongside other international corporate social responsibility and human rights norms.

Government, business and civil society networks have also provided significant channels for promoting the UNGPs at the regional level. The ASEAN People's Forum and ASEAN Civil Society Conference have provided useful forums to facilitate civil 
society advocacy around business and human rights issues; while networking amongst National Human Rights Institutions has been coordinated through the Southeast Asian National Human Rights Institutions Forum. The ASEAN Intergovernmental Commission of Human Rights has also engaged with the business and human rights agenda through carrying out a Baseline Study on Corporate Social Responsibility and Human Rights in ASEAN and facilitating seminars and dialogue events with government, business and civil society representatives to promote awareness-raising, capacity-building and knowledge-sharing. Such initiatives have received some support from regional business networks such as the ASEAN Corporate Social Responsibility Network and ASEAN Responsible and Inclusive Business Alliance, though explicit engagement with the UNGP framework within such forums has remained limited, but discussions have tended to remain framed around corporate social responsibility rather than human rights discourses.

Transnational market-based regulatory processes have provided another important channel of UNGP dissemination in sectors with strong connections into global supply chains, such as palm oil, and pulp and paper. In these sectors, pressure from European consumers, businesses and governments for compliance with international standards such as the UNGPs has generated strong incentives for local businesses to engage with these norms as a means of retaining access to international markets. The influence of such international norms is intensified for those companies choosing to participate in product or sector-based standard-setting and certification schemes, such as the Roundtable on Sustainable Palm Oil, whose credibility among global civil society and consumer audiences also depends on alignment with international human rights norms. The Roundtable on Sustainable Palm Oil (RSPO) introduced a new human rights standard into its Principles and Criteria in 2013 which made explicit reference to the UN Guiding Principles, alongside other international human rights instruments. Later that year, in November 2013, the RSPO General Assembly passed a resolution for the formation of a new RSPO Working Group on Human Rights, aiming to provide the RSPO Secretariat and members with "a better understanding and supportive tools to effectively implement 
the UN Guiding Principles on Business and Human Rights". Reforms to the RSPO complaint system that occurred around the same time also incorporated reforms that aligned the complaints system more closely with the UN Guiding Principles, particularly Principle 31 on the effectiveness of non-judicial grievance mechanisms. Such shifts illustrate the importance not only of governmental and intergovernmental networks as means of disseminating the UNGPs, but also the role of market and multi-stakeholder networks operating at transnational scale.

\section{Uneven implementation outcomes}

Despite such efforts to promote the UNGPs through collaborative learning networks at multiple scales, the extent to which the UNGPs have achieved recognition and impact has varied widely across countries, sectors and individual companies within Southeast Asia. While the channels of UNGP dissemination identified above provide localised opportunities for information-sharing and learning, wider patterns of implementation in the region have remained limited and uneven. For example, a recent study of the extent to which the most prominent listed companies in ASEAN countries had implemented UNGP guidelines concerning disclosure of corporate policies for managing human rights impacts revealed both low overall levels of implementation (companies disclosing on average only a little over $20 \%$ of the information requested by the UNGPs), and high levels of variation (estimates ranging between $8.9 \%$ in the Philippines and $42.6 \%$ in Thailand).

Such uneven patterns of implementation are in a sense consistent with the expectations of key UNGP architects such as John Ruggie, who have explicitly conceptualised UNGP diffusion as unfolding within a fragmented, polycentric governance system in which implementation advances through gradual and cumulative pathways of progressive change. Building on the core constructivist assumptions of such a view, uneven implementation is frequently explained primarily as a product of uneven opportunities for dialogue and learning. However, a contrasting explanation for varied implementation outcomes, which often receives 
less emphasis in scholarly conversations about UNGP implementation, focuses on configurations of market, political and civil society pressure to respond to international human rights standards. The significance of such sources of pressure as determinants of implementation outcomes is clearly evident in Southeast Asia, where recognition and implementation of the UNGPs has varied significantly between firms, countries and sectors.

Firm ownership and governance structures play an important role in shaping the vulnerability of different firms to market pressures to comply with international human rights standards. Family and state-owned enterprises play a prominent role in many sectors in the region. Particularly when these firms are not listed on stock exchanges, they escape some sources of public pressure to which publicly-listed companies are subject. Market pressure to comply with international human rights norms also varies significantly between companies depending on dominant sources of corporate or project financing. Where western banks and governments or international financial institutions play a significant role in financing business activity, pressures to adhere to international human rights standards can be powerful-such sources of finance often being conditional on compliance with international standards such as the Equator Principles or International Finance Corporation Performance Standards, both of which provide means of assessing and managing social and environmental risk which incorporate some international human rights norms. However, as both private and government financing from within the Asian region continues to rise in significance in a range of sectors, such sources of market pressure are often weakened.

The influence of the UNGPs has also varied significantly between countries and economic sectors. Varied capacity of civil society to mobilise around human rights issues in part reflects the enormous diversity of political systems and democratic histories within the region and associated orientations towards political and civic rights and media freedoms. Differences in the freedoms and capacities of civil society to pressure business to implement the UNGPs also reflect varied structures and histories of interest group organisation, connections between domestic and 
transnational civil society networks, and broader state approaches to the facilitation, regulation or repression of civil society organisations.

The capacity of business interests to influence or capture state regulatory processes also varies widely between countries and sectors, in turn reflecting differences in factors such as state regulatory capacity, business-state linkages and cultures of corruption or regulatory capture. In many countries and sectors in the region, the influence of international human rights norms is constrained by powerful linkages between state and business interests, variously taking the form of oligarchic patronage networks, money politics, or the personal financial interests of political and bureaucratic elites in particular companies or sectors. Such barriers are often intensified by a broader state responsiveness to business interests, reflecting the structural demands of policy regimes oriented towards promoting industrialisation, inward investment and export growth. In contrast, human rights norms are more likely to receive support in the presence of strong state-society linkages between rights-oriented civil society groups and political and bureaucratic actors sympathetic to human rights norms, or where there are strong linkages to international organisations or foreign governments incorporating rights agendas into their diplomatic engagements and development cooperation programs.

Despite multiple pathways through which the UNGPs have been disseminated within the region, the reach and impact of these Principles have thus remained critically dependent on the capacity of market, civil society and government actors to mobilise incentives for change. Where such pressures are weak or absent, UNGP implementation within the region has remained negligible. Yet while the promise of cumulative change achieved through cascading processes of norm diffusion and learning suggests a trajectory of rising recognition and penetration of global human rights norms, in many countries in Southeast Asia it is also possible to observe counter-movements towards shrinking political space for liberal international norms, intensifying threats to civil society freedoms and security, and the declining leverage of western markets and governments. In this challenging environment, continued progress towards implementation of the business and human rights agenda demands 
a sustained focus on creating and defending political and civic spaces through which pro-rights actors inside and outside of the state can generate substantive pressure for change.

\section{Navigating the politics of UNGP implementation}

The above analysis not only helps us to understand variation and pervasive limits of the UNGPs' influence in Southeast Asia, it also has prescriptive implications for discussions about ongoing implementation strategies. While much emphasis has been placed on promotion of socialisation and learning within collaborative governance networks, this article's analysis has highlighted the importance of multiple sources of social and economic pressure for change. Such pressure can come not only from invigorated regulatory interventions by governments, but also from consumers, banks, international financial institutions, and civil society organisations, all of which play a potentially important role in mobilising pressure for meaningful UNGP implementation. As Rodriguez Garavito has argued in a recent book on the future of the global business and human rights agenda, building a political foundation for UNGP implementation demands political changes that "facilitate the exercise of countervailing power" by civil society organisations and other participants in rights coalitions, thus at least partially countering the forms of business and state power that are so often deployed as a means of resisting or circumventing implementation of international human rights norms. Through strengthening coalitions of state, market and civil society actors who seek to promote the UNGPs, efforts to extend UNGP implementation within Southeast Asia may continue to make some substantive inroads, despite the persistent and, in many respects, intensifying obstacles that confront the business and human rights agenda in the region.

Image: Worker at a jade mine. Credit: Wikimedia Commons. 